\title{
Spatiotemporal patterns of wolf, mesocarnivores and prey in a Mediterranean area
}

\author{
Mariana Rossa ${ }^{1,2} \cdot$ Sandro Lovari ${ }^{1,3} \cdot$ Francesco Ferretti $^{1,4}$ (1) \\ Received: 30 July 2020 / Revised: 15 December 2020 / Accepted: 21 December 2020 / Published online: 20 January 2021 \\ (C) The Author(s) 2021
}

\begin{abstract}
Spatial and temporal occurrence can mediate behavioural interactions between apex predators, mesocarnivores and herbivores. Predators should adapt their activity to that of prey, whereas predator avoidance would be expected to influence activity patterns and space use of prey and smaller competitors. We evaluated interspecific spatiotemporal relationships in a prey-rich community including an apex predator (the wolf), three wild ungulates and several smaller herbivores/mesocarnivores, through camera trapping. All considered species (i.e. wolves and potential prey/smaller competitors: wild boar, fallow deer, roe deer, crested porcupine, red fox and European badger) were active especially at night and/or twilight. Among wild ungulates, the wolf showed the greatest temporal overlap with the wild boar and the lowest one with the least abundant and used of them, i.e. the roe deer. The main prey (i.e. the fallow deer) showed more diurnal activity and a lower temporal overlap with the predator in sites with high wolf activity than in low-activity ones. Among mesocarnivores, the red fox showed extensive temporal overlap with the wolf: the overlap between the two canids was greater in sites intensively used by this apex predator than in sites with low wolf activity, supporting a concurrent study which suggested a potential for facilitative - rather than competitive - interactions. Spatiotemporal relationships suggest complex interactions between the apex predator, prey and smaller carnivores, for which a substantial temporal or spatial association was often supported.
\end{abstract}

\section{Significance statement}

There is a growing interest in the influence of apex predators on ecosystems through their effects on the behaviour of prey and smaller carnivores, especially in the light of the ongoing recovery of large carnivores in temperate areas. Predators should synchronise their activity to that of prey; conversely, prey and smaller carnivores would be expected to avoid predators. In a rich community including the wolf, three wild ungulates and several mesomammals, we detected $(i)$ a substantial temporal overlap between wolves and wild boar, porcupines and mesocarnivores; (ii) a negative temporal association between the predator and its main prey (i.e. the fallow deer) and (iii) a great temporal overlap between the wolf and the red fox. We provide a baseline to evaluate temporal changes of predator-preymesocarnivore behavioural interactions along with variations of carnivore-prey densities.

Keywords Avoidance $\cdot$ Facilitation $\cdot$ Interspecific interactions $\cdot$ Predator-prey relationships $\cdot$ Ungulates

Communicated by K. Eva Ruckstuhl

Francesco Ferretti

francesco.ferretti@unisi.it

1 Research Unit of Behavioural Ecology, Ethology and Wildlife Management, Department of Life Sciences, University of Siena, Via PA Mattioli 4, 53100 Siena, Italy

2 CESAM, Department of Biology, University of Aveiro, Campus de Santiago, 3810-193 Aveiro, Portugal

3 Maremma Natural History Museum, Strada Corsini 5, 58100 Grosseto, Italy

4 Maremma Regional Park Agency, Via del Bersagliere 7/9, 58100 Alberese (Grosseto), Italy

\section{Introduction}

Apex predators are expected to influence the behaviour of prey and smaller carnivores (Palomares and Caro 1999; Schmitz et al. 2000), with ensuing effects at individual-topopulation scales (Estes et al. 2011; Ripple et al. 2014; Ford et al. 2014). As a result, the action of apex carnivores can trigger top-down cascading effects on biology and ecology of organisms belonging to lower trophic levels, with potential consequences at the ecosystem level (e.g. Estes and Palmisano 1974; Hebblewhite et al. 2005; Ripple et al. 2014). Effects on prey are univocally primed by predation (e.g. Sinclair et al. 
2003; Fortin et al. 2005), but relationships between apex predators and mesocarnivores are less obvious (e.g. Ritchie and Johnson 2009; Prugh and Sivy 2020). Medium-sized carnivores can suffer from intra-guild competition with larger competitors (Palomares and Caro 1999; Donadio and Buskirk 2006). For instance, the Mesopredator Release Hypothesis (Soulé et al. 1988) suggests that the decline of apex predators can ecologically "release" mesocarnivores, in turn increasing their predation on a wider range of other prey (e.g. Crooks and Soulé 1999; Ritchie and Johnson 2009). However, mesocarnivores can also benefit from feeding on prey leftovers of apex predators, thus being facilitated by them (Selva and Fortuna 2007; Allen et al. 2015; Sivy et al. 2018).

The presence of a predator can trigger the development of anti-predator behavioural strategies, e.g. through the increase of frequency and/or duration of vigilance postures, increase of group size and/or behaviours limiting the spatial and/or temporal overlap with the predator (Fortin et al. 2005; Périquet et al. 2010; Ross et al. 2013). Prey have been shown to modify their behaviour to balance between the necessity to feed and the risk of encountering predators (Theuerkauf et al. 2003; Linkie and Ridout 2011). This balance may involve the temporal avoidance of sites where the perceived predation risk is high (Linkie and Ridout 2011). Conversely, predators are also dependent on their relationship with prey and should be expected to adapt their hunting behaviour and activity to match activity patterns of their prey (Kronfeld-Schor and Dayan 2003; Theuerkauf et al. 2003; Foster et al. 2013). Therefore, temporal and spatial overlapping between predators and prey are expected to depend on this trade-off between feeding (for both species) and predator avoidance (only for the prey).

The coexistence between different species of carnivores is achieved through partitioning of the ecological niche in relation to temporal, spatial and/or trophic components (Schoener 1974; Kronfeld-Schor and Dayan 2003). Interspecific interference, escalating up to the killing of the smaller species by the larger one, is a key determinant of interactions between carnivores (Palomares and Caro 1999; Donadio and Buskirk 2006, for reviews). In turn, smaller species are expected to develop mechanisms leading to avoid encounters with larger ones, e.g. by adjusting their activity and movements $(\mathrm{Bu}$ et al. 2016; Torretta et al. 2016).

Avoidance of the top predator would be expected to occur in both prey and mesocarnivores, whereas the former would be predicted to adapt its behaviour to that of its main prey (Lima 2002; Foster et al. 2013). Most studies investigated predator-prey or apex predator-mesocarnivore interactions separately (e.g. Monterroso et al. 2013; Haswell et al. 2018). Conversely, studies dealing with relationships between top predators and both prey and meso-carnivores at the same time are scarce (Mori et al. 2020). We considered interspecific spatiotemporal interactions in a community including an apex predator (the wolf Canis lupus), three wild ungulates (the wild boar Sus scrofa, the fallow deer Dama dama and the roe deer Capreolus capreolus) and eight medium-sized mammals. Moreover, we investigated whether activity patterns of prey/mesocarnivores differed between sampling sites more/less used by the apex predator. During our study, fallow deer and wild boar built up more than $75-80 \%$ of the diet of wolves, with other wild mammals being $c .10-15 \%$ of diet, in terms of occurrences, volume or biomass (Ferretti et al. 2019). We have tested the following predictions: (i) temporal overlap of the fallow deer and the wild boar with the wolf would be greater than that of roe deer, porcupine and mesocarnivores with this apex predator; (ii) for all species, activity overlap with the wolf would be lower in sites highly used than in sites less used by this apex predator and (iii) the potential for spatial association would be greater between the wolf and its main prey (wild boar and fallow deer) than between the apex predator and other study species.

\section{Materials and methods}

\section{Study area}

Our study was conducted in a c. $30 \mathrm{~km}^{2}$ sector of the Maremma Regional Park (c. $90 \mathrm{~km}^{2}$, Central Italy, $42^{\circ} 39^{\prime}$ $\mathrm{N}, 11^{\circ} 05^{\prime} \mathrm{E}$; Fig. 1). The climate is Mediterranean, with dry summers and wet winters, a mean seasonal rainfall of $c$. $72 \mathrm{~mm}$ in summer, $143 \mathrm{~mm}$ in spring, 202 in winter and $229 \mathrm{~mm}$ in autumn (RDM 2002). Mean annual rainfall is $c$. $670 \mathrm{~mm}$ and mean annual temperature is $13.2-15.5^{\circ} \mathrm{C}(\mathrm{RDM}$ 2002). The study area lies on the northern sector of Uccellina hills (maximum elevation: $417 \mathrm{~m}$ a.s.l.) and the Granducale Pinewood. Vegetation is dominated by Mediterranean sclerophyllic scrubland on the hills and by Pinus spp. in the pinewood (Sforzi et al. 2012; Melini et al. 2019). Other habitats are olive groves, some of them with shrubs, and meadows, with abundant Juniperus oxycedrus macrocarpa along the sandy dune next to the Mediterranean Sea (Fig. 1).

Wild boar (c. 10-13 individuals/100 ha during our study, estimated through faeces counts), fallow deer (c. 9 ind.s/ 100 ha) and roe deer (c. 5-7 ind.s/100 ha) occur in our study area (Ferretti et al. 2019). Mesocarnivores are the red fox Vulpes vulpes, the European badger Meles meles, the wildcat Felis silvestris, the stone marten Martes foina, the pine marten and Martes martes; other meso-mammals are the European brown hare Lepus europaeus, the crested porcupine Hystrix cristata and the coypu Myocastor coypus (an alien invasive species). A pack of wolves Canis lupus was present in the study area at the time of our study; a second pack formed in 2017, north of the Ombrone river, and may have visited the area (Ferretti et al. 2019). Further details on the study area are provided in Ferretti et al. (2019). 


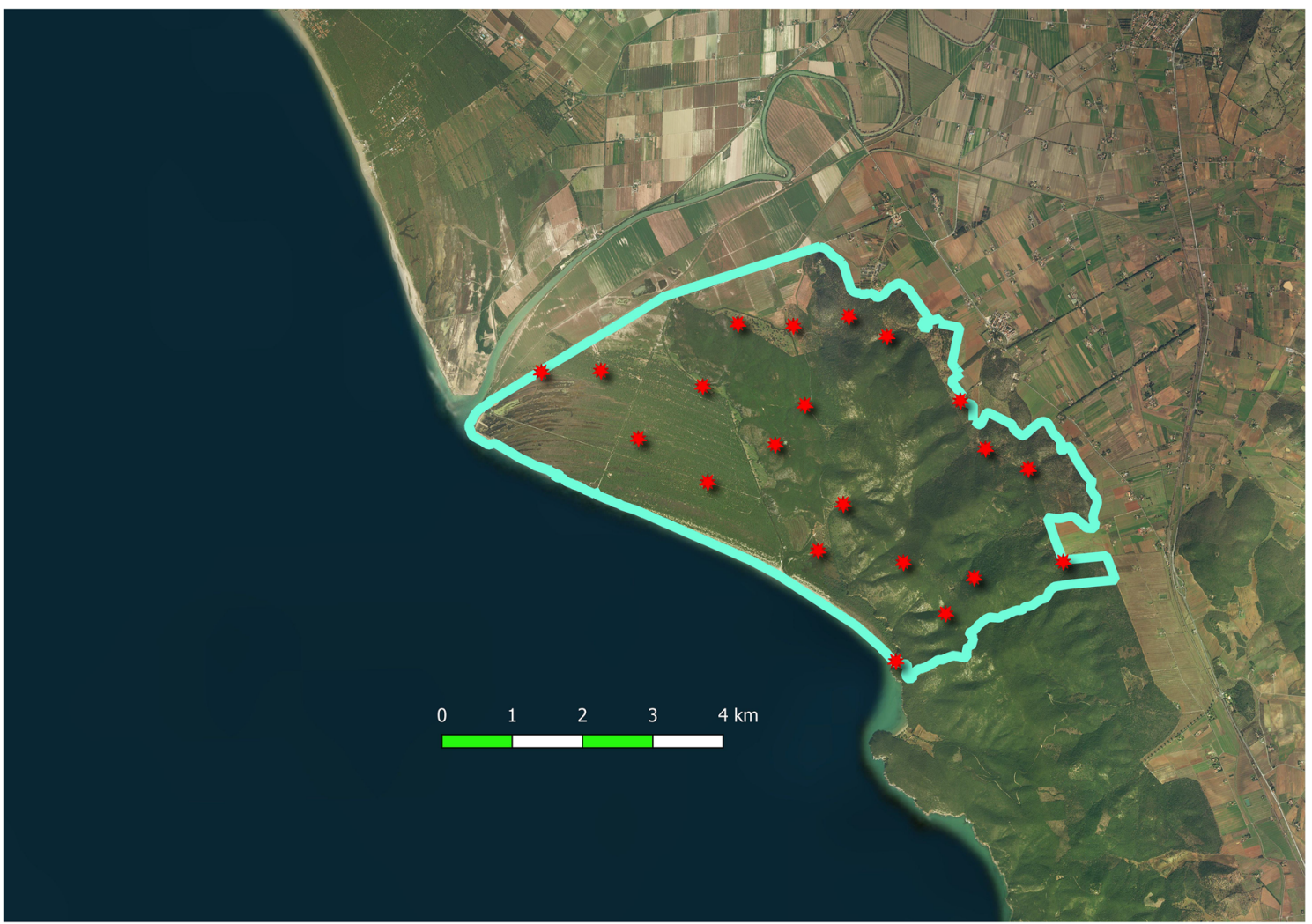

Fig. 1 Map of the study area with locations of camera traps. The pale blue solid line indicates the borders of our study area

\section{Camera trapping}

Temporal activity patterns were assessed using camera trapping. A sampling grid (cell size: $1.3 \mathrm{~km} \times 1.3 \mathrm{~km}$ ) was superimposed to the study area through a Geographic Information System (GIS) (Li et al. 2012; Bu et al. 2016). Between September 2017 and August 2018, twenty-one camera trapping locations were defined (1 location per grid cell). On September 2017, 7 cameras were put on site, along trails or forest roads, at a height of $30-60 \mathrm{~cm}$ from the ground (Torretta et al. 2017). Cameras were subsequently rotated to other 7 locations monthly, to monitor all 21 locations for at least $c$. 1 month/season ("autumn": September-November; "winter": December-February; "spring": March-May; "summer": June-August), i.e. each location was monitored c. 4 months throughout the study (Fig. 1). Each month, we considered a minimum distance of at least $1 \mathrm{~km}$ between each pair of neighbour cameras.

We used IR-Plus HD-2 cameras, triggered by an infrared motion sensor. The cameras were supplied with 16 GB SD cards and external batteries and set to operate continuously (i.e. $24 \mathrm{~h}$ per day). The cameras were set to record videos of $30 \mathrm{~s}$ with a minimum time lag between consecutive ones of $5 \mathrm{~s}$; trigger time was $1 \mathrm{~s}$. The cameras were inspected every 12 weeks to replace batteries and memory cards and relocated every 4 weeks. The sampling effort at each location was the number of days between installation and collection of the camera (Li et al. 2012). When batteries ran flat before they had been replaced, the time of the last exposure was determined from the downloaded videos and considered as the last operational date (Rowcliffe et al. 2008; Li et al. 2010).

\section{Temporal activity patterns}

For all videos, the date and the solar time of capture were recorded. From each video, we obtained the following information: date, time, species, number of individuals and camera location, and we inserted them in a dataset. Videos were screened and analysed by two of us (MR and FF). To limit pseudoreplication, when the same camera trap took more than 1 video of the same species in less than $30 \mathrm{~min}$ (Monterroso et al. 2014; Torretta et al. 2017), we counted them as 1 event and used the time at which the first video was taken for subsequent analyses (Tobler et al. 2008; Lucherini et al. 2009; Torretta et al. 2016; de Satgé et al. 2017). The record of each species was categorised as: daytime (between $1 \mathrm{~h}$ after sunrise and $1 \mathrm{~h}$ before sunset), night (between $1 \mathrm{~h}$ after sunset and $1 \mathrm{~h}$ before sunrise), dawn (from $1 \mathrm{~h}$ before sunrise to $1 \mathrm{~h}$ after sunrise) and dusk (from $1 \mathrm{~h}$ before sunset to $1 \mathrm{~h}$ after sunset) (Lucherini et al. 2009). The sunrise and sunset hours were obtained for the study area on each recorded date, using Moonphase SH 3.3 software (see Pratas-Santiago et al. 2016). The selection for different time periods (night, dawn, 
daytime, dusk) was evaluated using Ivlev's index of selectivity (Ivlev 1961) for each species.

Temporal activity patterns and associated $95 \%$ confidence intervals were assessed for each considered species. For each species, we calculated diel activity patterns using Kernel density estimation. The obtained density functions used the time variable as continuous and circular (Bu et al. 2016), instead of defining discrete time categories. Graphically, the area under the function obtained corresponds to the probability of observing the animal for each period of time (Foster et al. 2013). The Watson's two-Sample test of homogeneity was calculated to test the uniformity of the distribution (Lund et al. 2017). All these analyses were conducted at yearly and 6-month temporal scales (i.e. "colder" season: September-February; "warmer" season: March-August). It was not possible to record data blind because our study involved focal animals in the field.

\section{Interspecific relationships}

According to Ridout and Linkie (2009), we estimated yearly and 6-month interspecific temporal overlap between the wolf and the other study species through the non-parametric calculation of the overlap coefficient, ( $\Delta$ : Weitzman 1970). This is an estimate of the overlap between two activity patterns corresponding to two species, ranging from 0 (no overlap) to 1 (complete overlap) (Linkie and Ridout 2011). We adopted the $\Delta_{1}$ coefficient when sample size was lower than 75 , and the $\Delta_{4}$ one when the number of recorded videos was $>75$ (Ridout and Linkie 2009). We calculated the $95 \%$ confidence intervals for overlap coefficients as percentile intervals from 999 bootstrap samples (Meredith and Ridout 2017). Moreover, for each location, species and temporal scale, we calculated the passage rate as number of events/number of days when the camera was actually operating. Then, we tested the correlation between passage rates of each species and that of the wolf through the Pearson's correlation coefficient, to evaluate the potential for spatial association between the apex predator and prey/meso-carnivores.

\section{Temporal activity patterns in sites with high vs. low wolf activity}

We compared the temporal activity patterns of potential prey (ungulates; porcupine) and mesocarnivores between sites with high and low frequency of wolf activity. For each location and temporal scale, we calculated the rate of wolf passages as described above. Then, we calculated the average passage rate across locations (Oberosler et al. 2017). We considered as sites with high wolf activity those with passage rates greater or equal to the mean value (i.e. 0.16 events/day at the yearly scale; 0.21 events/day in the colder season; 0.11 events/day in the warmer season). Conversely, we considered as sites with low wolf activity those with passage rates lower than the mean passage rate. In this way, we defined 5-6 locations as "high wolf" and 15-16 locations as "low wolf", depending on the study period (see below). Then, we compared activity patterns of each species (potential prey/mesocarnivores) between locations with high and low wolf activity. All these comparisons were based on coefficients of temporal overlap and Watson's test for homogeneity. Statistical analyses were conducted through the R software, version 3.4.2 (R Core Team 2020), using the "circular" and "overlap" packages (Lund et al. 2017; Meredith and Ridout 2017).

\section{Data availability}

The datasets generated and/or analysed during the current study have been collected under an agreement between the Maremma Regional Park Agency and the Institution of the corresponding author (Department of Life Sciences, University of Siena) and are available from the corresponding author on reasonable request and upon permission of the above mentioned parties.

\section{Results}

\section{Temporal activity patterns}

Over a total of 2104 trapping days (Colder season: $n=1149$; Warmer season: $n=955$ ), we collected 4912 videos (Colder season: $n=3239$; Warmer season: $n=1673$; Table 1). All study species were active especially at night or at dawn/dusk (Fig. 2; Watson test: $U=1.07-6.38, p<0.01$; Supplementary Material: Table S1 and Figs. S1, S2, S3), but for the fallow deer, which showed temporal activity patterns not differing significantly from homogeneity $(U=0.15, p>0.05)$. The wild boar showed a preference for dusk-night periods. Night was clearly avoided by roe deer, which selected dawn/dusk periods. The wolf also selected dawn whereas fallow deer selected dusk (Fig. S3). These patterns were confirmed by analyses

Table 1 Number of camera-trap records of each study species at the 1year scale and for each 6-month period (Colder season: September 2017February 2018; Warmer season: March-August 2018)

\begin{tabular}{llll}
\hline Species & Colder season & Warmer season & Year \\
\hline Wolf & 253 & 117 & 370 \\
Wild boar & 781 & 263 & 1044 \\
Fallow deer & 1323 & 799 & 2122 \\
Roe deer & 25 & 40 & 65 \\
Red fox & 650 & 280 & 930 \\
European badger & 39 & 46 & 85 \\
Crested porcupine & 168 & 128 & 296 \\
\hline
\end{tabular}



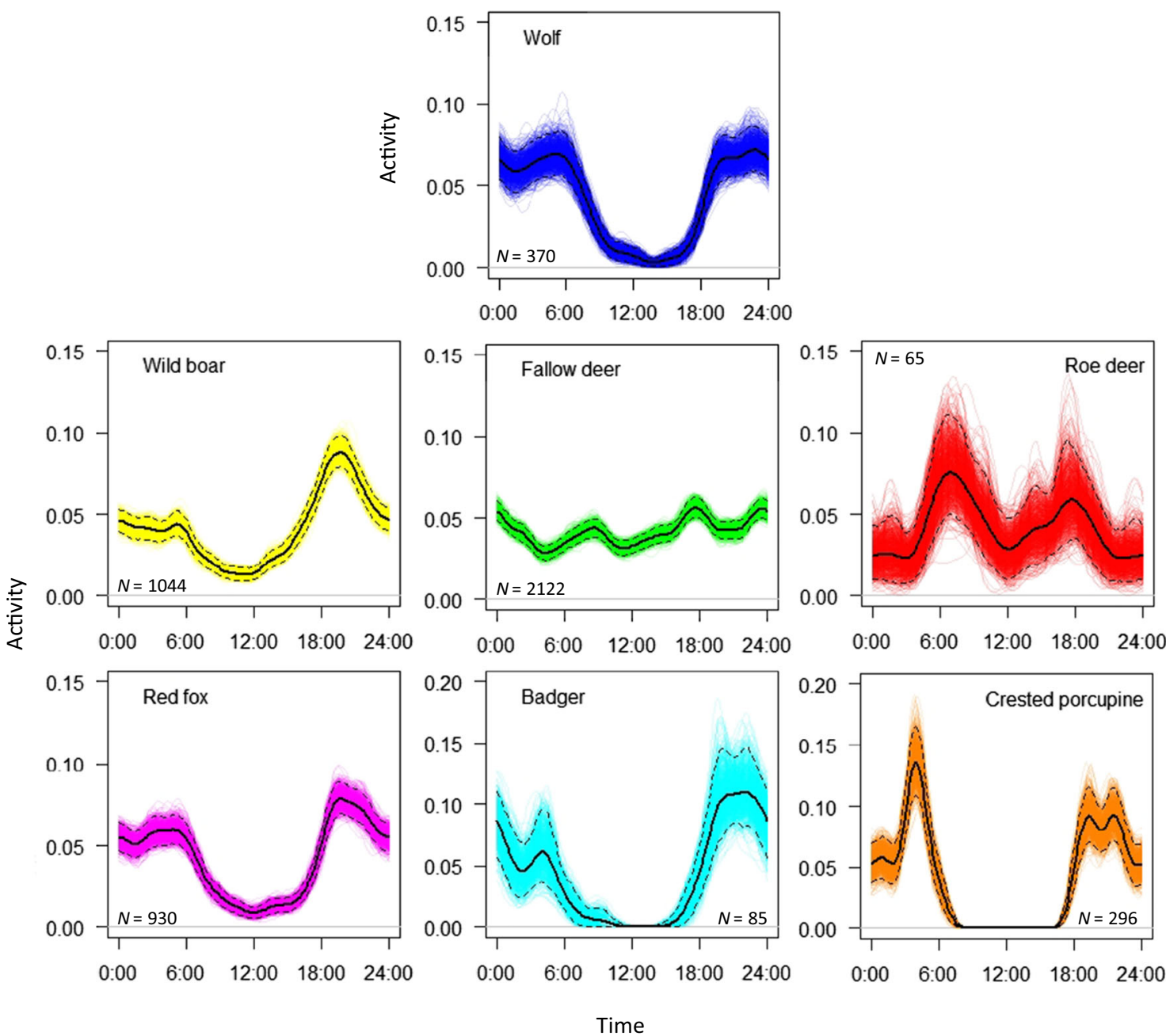

Fig. 2 Temporal activity patterns of medium-sized and large mammals (September 2017-August 2018). Coloured lines represent bootstrapped estimates of activity patterns; dashed black lines represent $95 \%$ confidence intervals

at 6-month temporal scales (Table S1 and Figs. S1, S2). However, the wild boar avoided dusk in the colder season, whereas porcupines also selected dusk and dawn, in the warmer season (Table S1).

\section{Interspecific relationships}

Among all study species, the red fox showed the greatest temporal overlap with the wolf $(\Delta=0.89)$, whereas the crested porcupine, badger and wild boar showed overlaps greater than $0.75(\Delta=0.77-0.79)$, followed by fallow deer $(\Delta=$ 0.72 ) and roe deer $(\Delta=0.62)$ (Fig. 3). This pattern was generally confirmed at a 6-month scale (Fig. 3; Figs. S4, S5).

Passage rates of wolves were slightly correlated to those of wild boar at the yearly scale and in the colder season $(r=$ $0.37-0.43, p=0.05-0.09$ ), but not in the warmer season $(r=-0.09, p=0.694)$. No significant correlation was found with fallow deer and roe deer $(r=-0.30-0.03, p>0.17)$. A positive correlation was observed between the wolf and the porcupine $(r=0.61-0.75, p<0.003)$ and between the wolf and mesocarnivores (red fox: $r=0.50-0.62, p=0.002-0.02$; badger: $r=0.41-0.70, p=0.001-0.06$ ).

\section{Temporal activity patterns in sites with high vs. low} wolf activity

These analyses were conducted on wild boar, fallow deer, red fox and crested porcupine, because of sample size constraints for the other species (Table 2). At all temporal scales, activity patterns of wild boar, fallow deer and red fox differed between "high wolf" and "low wolf" sites $\left(U^{2}=0.19-1.72, p<0.05\right)$, but differences were not significant for the porcupine $\left(U^{2}=\right.$ $0.12-0.15, p>0.05$ ) (Figs. S6, S7). Temporal activity patterns of fallow deer and wild boar were significantly different from those of wolves in both sites with high and low wolf activity $\left(U^{2}=0.25-4.36, p<0.05\right)$, with the exception of the warmer season, in "low" wolf sites $\left(U^{2}=0.07-0.14, p>0.05\right)$. At the 6-month scale, temporal activity of the fox was comparable to that of the wolf in "high wolf" sites and, in the warmer season, in low wolf sites $\left(U^{2}=0.07-0.15, p>0.05\right)$. At 1 -year scale 
Fig. 3 Coefficients of interspecific overlap $(\Delta 4)$ of temporal activity patterns between the wolf and 6 species of mammals with $95 \%$ confidence intervals at 1-year scale and for each 6-month period (colder season: September 2017February 2018; warmer season: March-August 2018)

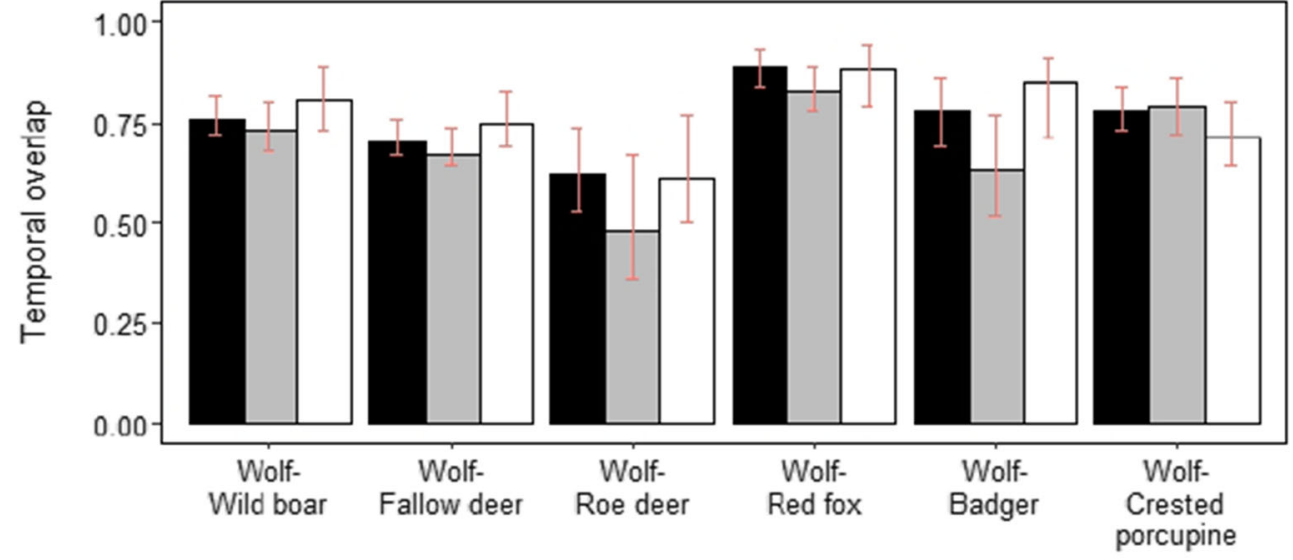

Year

Colder Warmer and in "low wolf" sites (colder season), activity patterns of the fox differed significantly from those of the wolf $\left(U^{2}=0.18-\right.$ $0.26, p<0.05)$. Activity patterns of the porcupine differed from those of the wolf in the warmer season and at the yearly scale $\left(U^{2}=0.26-0.48, p<0.05\right)$, but not in the colder season $\left(U^{2}=0.10-0.17, p>0.05\right)$.

Temporal overlap with the wolf tended to decrease in "high wolf" sites in respect to "low wolf" sites for fallow deer, whereas it showed the opposite pattern for red fox (Table 3). As examples, interspecific overlap between wolf and fallow deer and red fox, respectively, in sites with high vs. low wolf activity are shown in Figs. 4 and 5. In particular, in "high wolf" sites, fallow deer activity was higher during daylight periods than in "low wolf" sites (Fig. 4).

\section{Discussion}

We investigated temporal relationships between an apex predator and other species of the local community of mammals in a Mediterranean area recently recolonised by wolves. We discussed our results in the light of predator-prey and apex predator-mesocarnivore interactions.

Table 2 N. of camera-trap records of species at the 1-year scale and for each 6-month period (Colder season: September 2017-February 2018; Warmer season: March-August 2018), in sites with high vs. low wolf activity. Sites with high wolf activity ("High wolf") were defined as

\begin{tabular}{|c|c|c|c|c|c|c|}
\hline \multirow[t]{2}{*}{ Species } & \multicolumn{2}{|c|}{ Colder season } & \multicolumn{2}{|c|}{ Warmer season } & \multicolumn{2}{|l|}{ 1-year } \\
\hline & High wolf & Low wolf & High wolf & Low wolf & High wolf & Low wolf \\
\hline Wild boar & 362 & 419 & 114 & 149 & 476 & 568 \\
\hline Fallow deer & 432 & 891 & 252 & 547 & 684 & 1438 \\
\hline Red fox & 258 & 392 & 142 & 138 & 400 & 530 \\
\hline Crested porcupine & 71 & 97 & 74 & 54 & 145 & 151 \\
\hline
\end{tabular}

\section{Predator-prey interactions}

In the absence of heavy human disturbance, apex predators are expected to regulate their activity mainly according to their biological clock (Kronfeld-Schor and Dayan 2003), thus adjusting it to the peak activity of their prey. Throughout our study, wolves showed bimodal activity patterns, with peaks at dawn and dusk, and with a higher nocturnal activity than that during the day (see also Theuerkauf 2009; Torretta et al. 2016; Smith et al. 2019). Presence of tourists is usually concentrated along the coast in late spring-summer, suggesting no major influence of human activity on our results.

Spatiotemporal overlap is usually high between apex predators and their main prey (Weckel et al. 2006; Arias-Del Razo et al. 2011; Basille et al. 2013; Courbin et al. 2013; Foster et al. 2013; Yang et al. 2018). In turn, prey is expected to adopt behavioural ploys to limit predation risk. Throughout our study, the fallow deer was the main prey of wolves (Ferretti et al. 2019). In our study area, local aggregation and accessibility of fallow deer herds in ecotone/open habitats have been suggested to favour their selection by wolves (Ferretti et al. 2019). A moderate temporal overlap occurred between predator and its main prey, whereas their passage

sites where the rate of wolf detections/day was equal or greater than the average value across all locations. Sites with low wolf activity ("Low wolf') were the sites where the rate of wolf detections/day was lower than the average value 
Table 3 Coefficients of temporal overlap and $95 \%$ confidence intervals between the wolf and wild boar, fallow deer, red fox and crested porcupine at yearly and 6-month temporal scales, in sites with high wolf activity and sites with low wolf activity. These analyses were conducted for these 4 species only, because of sample size constraints

\begin{tabular}{|c|c|c|c|c|c|c|c|}
\hline \multirow[t]{2}{*}{ Species pair } & \multirow[t]{2}{*}{ Period } & \multicolumn{3}{|c|}{ High wolf activity } & \multicolumn{3}{|c|}{ Low wolf activity } \\
\hline & & $\Delta$ & CI (lower) & CI (upper) & $\Delta$ & CI (lower) & CI (upper) \\
\hline \multirow[t]{3}{*}{ Wolf-Wild boar } & Year & 0.72 & 0.67 & 0.80 & 0.74 & 0.67 & 0.83 \\
\hline & Colder & 0.71 & 0.68 & 0.81 & 0.75 & 0.7 & 0.89 \\
\hline & Warmer & 0.78 & 0.73 & 0.93 & 0.71 & 0.64 & 0.89 \\
\hline \multirow[t]{3}{*}{ Wolf-Fallow deer } & Year & 0.57 & 0.54 & 0.64 & 0.71 & 0.66 & 0.82 \\
\hline & Colder & 0.58 & 0.55 & 0.67 & 0.76 & 0.72 & 0.88 \\
\hline & Warmer & 0.61 & 0.51 & 0.70 & 0.66 & 0.6 & 0.87 \\
\hline \multirow[t]{3}{*}{ Wolf-Red fox } & Year & 0.9 & 0.83 & 0.93 & 0.81 & 0.69 & 0.84 \\
\hline & Colder & 0.89 & 0.86 & 0.97 & 0.75 & 0.69 & 0.91 \\
\hline & Warmer & 0.88 & 0.84 & 0.98 & 0.67 & 0.59 & 0.87 \\
\hline \multirow[t]{3}{*}{ Wolf-Crested porcupine } & Year & 0.76 & 0.71 & 0.85 & 0.69 & 0.59 & 0.78 \\
\hline & Colder & 0.79 & 0.74 & 0.92 & 0.70 & 0.65 & 0.86 \\
\hline & Warmer & 0.69 & 0.64 & 0.84 & 0.61 & 0.53 & 0.83 \\
\hline
\end{tabular}

a

HIGH Wolf use

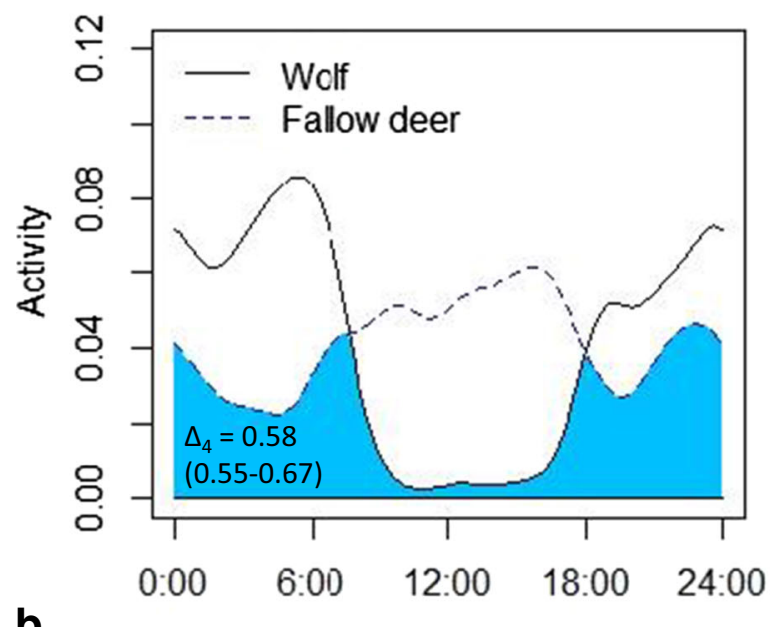

b

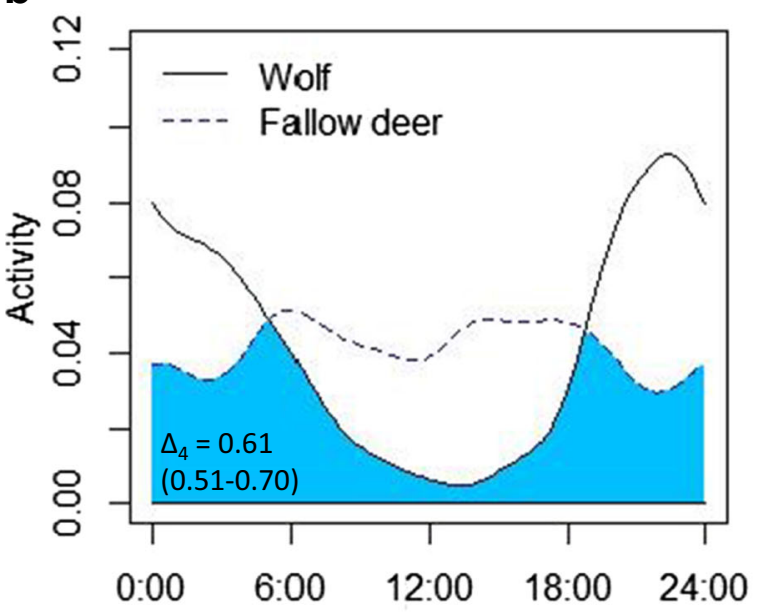

LOW Wolf use
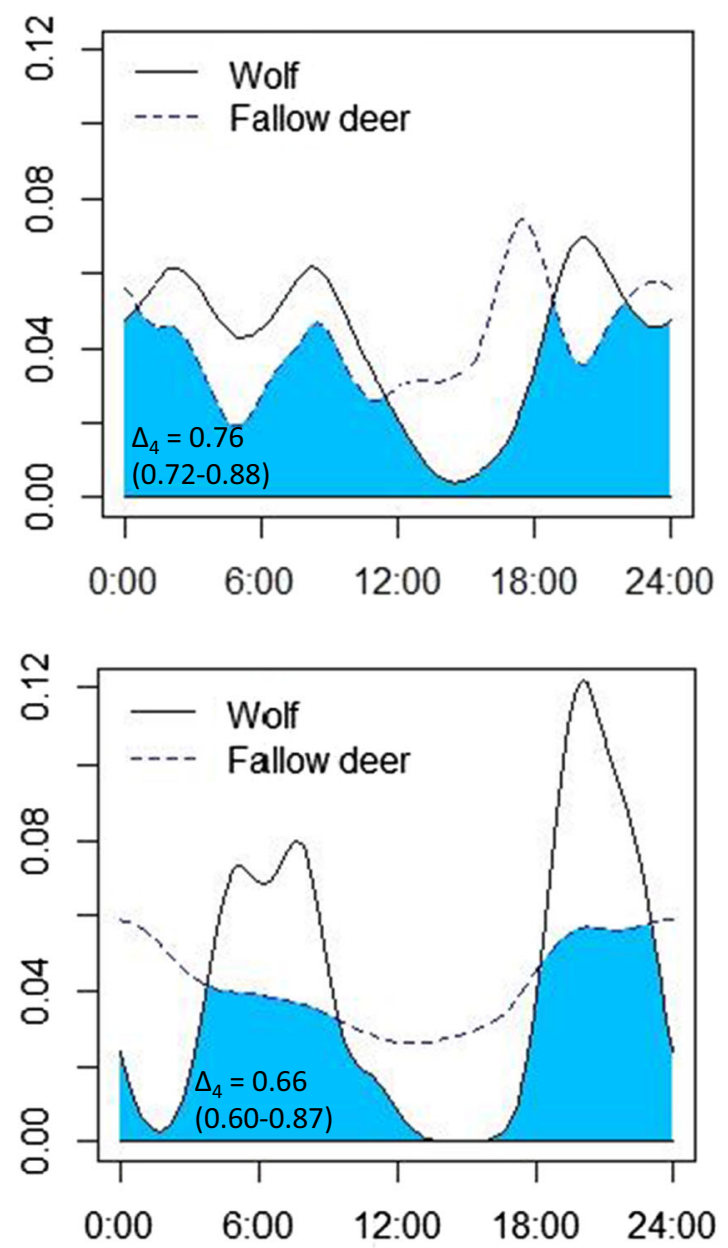

\section{Time}

Fig. 4 Example of interspecific temporal overlap in sites with high vs. low wolf activity: interspecific overlap of temporal activity patterns of wolf and fallow deer in the colder (a September 2017-February 2018) and warmer (b March-August 2018) seasons, in sites with high wolf activity (left) and sites with low wolf activity (right) 
HIGH Wolf use

a

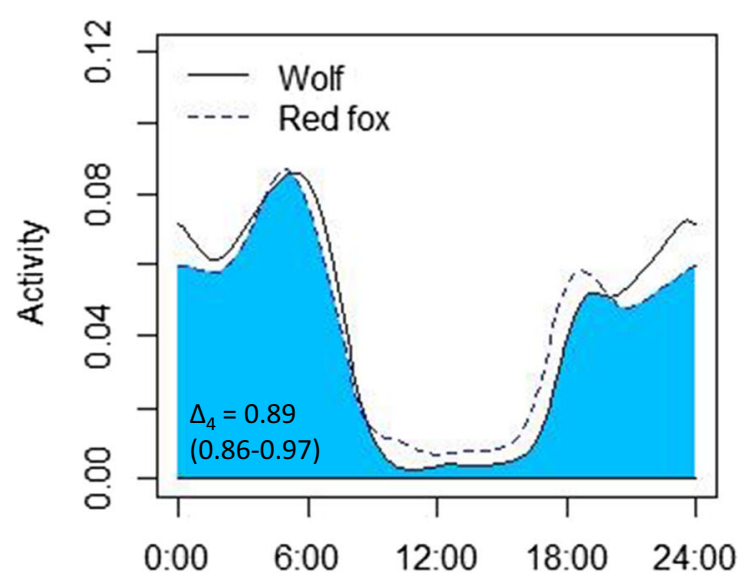

b

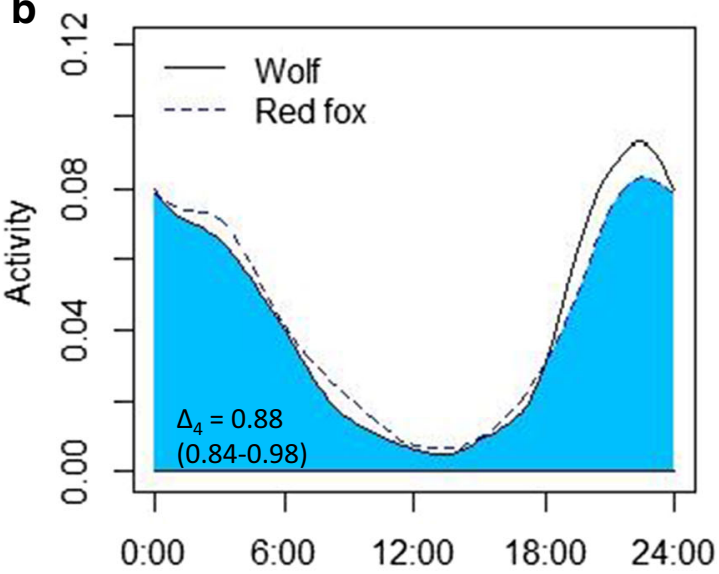

LOW Wolf use
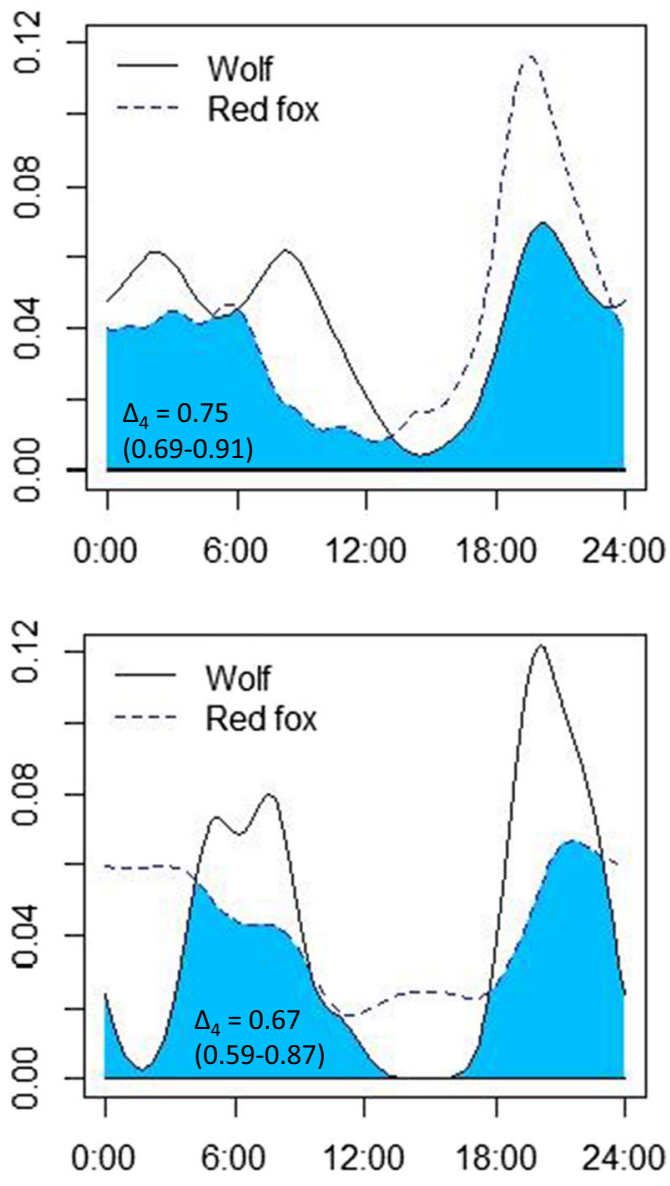

Time

warmer (b March-August 2018) seasons, in sites with high wolf activity (left) and sites with low wolf activity (right)

group size and/or surveillance may allow ungulates to remain at feeding places in the presence of predators (e.g. Creel and Winnie 2005; Liley and Creel 2008; Dröge et al. 2017). Our results are consistent with the risk of predation shaping activity patterns of main prey (e.g. Fischhoff et al. 2007; Tambling et al. 2015; Smith et al. 2019).

Species-specific anti-predatory behaviours would be expected to trigger different consequences on predator-prey interactions. In Mediterranean areas, usually the wild boar is the staple of the wolf diet (Mori et al. 2016 for a review), and a high spatiotemporal overlap between them has been reported (Mori et al. 2020). In our study area, it rated as the second prey of wolves (Ferretti et al. 2019). Several studies have reported the nocturnal activity of wild boar (Boitani et al. 1994; Campbell and Long 2010); we observed also a significant activity at dusk. Adult wild boar have been observed rushing to wolves approaching wild boar groups (our observations); conversely, we found no negative association between the wolf and the wild boar either temporally or spatially, 
with no significant difference in wild boar activity patterns between sites with high vs. low wolf activity. Our results support the argument that prey with a high probability of escaping from an encounter with the predator through active defence do not alter substantially their temporal or spatial behaviour as an anti-predatory response (Wirsing et al. 2010).

Among wild ungulates, the roe deer was the least used species by the wolf (Ferretti et al. 2019), with a low temporal overlap with the predator. The antipredator behaviour of roe deer has been reported as based on increased vigilance and spatiotemporal avoidance of sites with high predation risk (e.g. Bonnot et al. 2013; Sönnichsen et al. 2013; Lone et al. 2014). In our study area, behaviour, distribution and density of this ungulate have been shown to be negatively influenced by interspecific competition with the fallow deer (Ferretti et al. 2011; Ferretti and Fattorini 2020). Thus, roe deer avoidance of sites with high local density of fallow deer may limit the risk of encounters with wolves (Ferretti et al. 2019). Future work should evaluate potential joint effects of predation, predator activity and spatiotemporal, as well as numerical, interactions between roe deer and fallow deer, to test whether the action of the top predator may influence competition between these deer species.

The porcupine also showed substantial temporal overlap with the wolf, with no difference of temporal activity in sites with greater probability of encountering wolves. Porcupines have evolved in regions with a great richness of large carnivores (e.g. lion Panthera leo, leopard Panthera pardus or tiger Panthera tigris). Not surprisingly, defensive behaviour of this nocturnal rodent (Corsini et al. 1995; Mori et al. 2014; Lovari et al. 2017) is based on the use of quills, which can be quite effective weapons (Mori et al. 2013). Accordingly, occurrence of porcupine in the wolf diet was only occasional and, most likely, directed to young individuals (Ferretti et al. 2019).

\section{Predator-mesocarnivore interactions}

We predicted that the temporal overlap of the wolf with mesocarnivores would be reduced because of avoidance behaviour of the former by the latter (e.g. Palomares et al. 1996; Crooks and Soulé 1999; Vanak et al. 2009). Conversely, a substantial interspecific overlap was detected, with no negative association between the wolf and mesocarnivores either temporally or spatially. The red fox and the European badger show nocturnal and twilight activity (Cavallini and Lovari 1994; Rosalino et al. 2005; Barrull et al. 2014; Monterroso et al. 2014; Torretta et al. 2017). In our study area, their diet is largely based on invertebrates and fruits (e.g. Ciampalini and Lovari 1985; Cavallini and Lovari 1991; Mastroianni 2004; Gandolfi 2004; Ferretti et al. 2021), thus with a low potential for exploitative competition with the wolf. As to the badger, overlap with the wolf was lower in the colder than in the warmer season (see also Torretta et al. 2016). During the warmer season, this omnivorous mustelid has been shown to increase its trophic niche breath (Ciampalini and Lovari 1985), which would be consistent with a greater probability of encounters with the wolf.

The temporal overlap between the wolf and the fox was remarkable (cf. Torretta et al. 2016; Mori et al. 2020). Temporal overlap was greater in sites with "high wolf" activity than in sites less used by the predator. A concurrent study showed that, although c. $80 \%$ of the fox diet was based on invertebrates and fruits, the volume and occurrence of ungulates in fox diet showed a 2.8-3.5 increase in respect to times when the wolf was absent from the area, despite no major temporal changes in ungulate abundance (Ferretti et al. 2021). Moreover, wild ungulates occurred in the fox diet $c$. 3-8 times more often than smaller sized rodents or birds/reptiles, and the use of ungulates was $c$. 2 times greater in the colder than in the warmer season (Ferretti et al. 2021), suggesting that it did not depend on active predation on newborns, in spring (e.g. Aanes and Andersen 1996; Jarnemo et al. 2004). Snowfall is usually absent in our Mediterranean, coastal study area, supporting no climate-related increase of ungulate mortality in the colder months. Ferretti et al. (2021) suggested that red foxes benefited of additional foraging opportunities through wolf prey leftovers. Carcasses left by wolves may be an important food resource (Selva et al. 2005; Bassi et al. 2012; Wikenros et al. 2013), especially when the availability of alternative food is low (Cagnacci et al. 2003). Our results suggest temporal and spatial association between the red fox and the wolf, which would not agree with interspecific avoidance. If so, foxes could have developed a balance between the opportunity to obtain free food access and the risk of aggressive encounters with a dominant carnivore. Our results require confirmation through a longer-term study; future work should also assess potential long-term variations in the potential for competition vs. facilitation between these carnivores, as well as the impact of wolf abundance on fox populations (Pasanen-Mortensen et al. 2013; Wikenros et al. 2017).

\section{Conclusions}

There is a wide debate on top-down cascade effects triggered by the wolf on other components of ecological communities (e.g. Ripple et al. 2014; Martin et al. 2020; but see Mech 2012; Barber-Meyer 2015). While it has been suggested that the potential for wolves to influence behaviour and ecology of other organisms should be limited in ecosystems largely modified by human activities (Kuijper et al. 2016; Ciucci et al. 2020; Haswell et al. 2020), the ecological role of wolves should be more evident in complete ecological communities. In our study area, wild ungulates dominated the diet of wolves (Ferretti et al. 2019). Our results suggest that the local main prey, i.e. the fallow deer, showed different temporal activity patterns in sites differing for levels of wolf activity. Potential effects on the wolf food habits and prey selection remain to be assessed, i.e. whether 
wolves would switch their predation to alternative prey or rather they would match the temporal activity of fallow deer. Nevertheless, the potential for predation may be limited by temporal — but not spatial — avoidance of predators by prey, which should be confirmed and may reduce the potential for a spatial modulation of intensive browsing (Fortin et al. 2005; Kuijper et al. 2013, 2015; Flagel et al. 2016).

Mesocarnivores showed up rarely in the wolf diet, probably because of the local presence of abundant ungulate prey (Ferretti et al. 2019). If so, the development of behavioural adaptations based on spatiotemporal avoidance may have not been necessary. As to the red fox, a potential for facilitation from the wolf has been detected by a parallel study (Ferretti et al. 2021). Future work should assess wolf-fox behavioural and ecological relationships along with variation in wolf numbers and prey availability. The ongoing recovery of wolves in European countries (Chapron et al. 2014) would provide the opportunity to test predictions on short- and long-term effects of this apex predator on other ecosystem components, further clarifying eco-evolutionary determinants of multi-species interactions.

Supplementary Information The online version contains supplementary material available at https://doi.org/10.1007/s00265-020-02956-4.

Acknowledgments We are deeply indebted to L. Venturi and E. Giunta for their support to our research, as well as to the Park wardens (especially L. Tonini, G. Anselmi and G. Martini) for their continuous assistance in fieldwork. We thank the MRP Agency for logistic support, and Ente Terre Regionali Toscane as well as landowners who allowed us to conduct fieldwork. We thank students who helped in data collection/analysis (I. Belardi, B. ten Cate, G. Fini, C. Priore) L. Corlatti for suggestions in data analyses, as well as L. Chelazzi and A. Pastorelli for help and discussions. We are grateful to the Associate Editor K. Ruckstuhl, to E. Torretta and to an anonymous reviewer for improving an earlier draft of our manuscript.

Funding Open Access funding provided by Università degli Studi di Siena. Funding was provided by Maremma Regional Park Agency. This study was financially supported by the Maremma Regional Park Agency and by the German Society for Mammalian Biology (DGS Project Funding 2018).

\section{Compliance with ethical standards}

Conflict of interest The authors declare that they have no conflict of interest.

Ethical approval We received the appropriate permissions for conducting the study in the Maremma Regional Park from the responsible authorities. All applicable international, national, and/or institutional guidelines for the use of animals were followed. Ethical approval from ethics committee for involving animals was not required.

\section{References}

Aanes R, Andersen R (1996) The effects of sex, time of birth, and habitat on the vulnerability of roe deer fawns to red fox predation. Can J Zool 74:1857-1865
Allen ML, Elbroch LM, Wilmers CC, Wittmer HU (2015) The comparative effects of large carnivores on the acquisition of carrion by scavengers. Am Nat 185:822-833. https://doi.org/10.1086/681004

Arias-Del Razo I, Hernández L, Laundré JW, Myers O (2011) Do predator and prey foraging activity patterns match? A study of coyotes (Canis latrans), and lagomorphs (Lepus californicus and Sylvilagus audobonii). J Arid Environ 75:112-118. https://doi.org/10.1016/j. jaridenv.2010.09.008

Barber-Meyer SM (2015) Trophic cascades from wolves to grizzly bears or changing abundance of bears and alternate foods? J Anim Ecol 84:647-651. https://doi.org/10.1111/1365-2656.12338

Barrull J, Mate I, Ruiz-Olmo J, Casanovas JG, Gosàlbez J, Salicrú M (2014) Factors and mechanisms that explain coexistence in a Mediterranean carnivore assemblage: an integrated study based on camera trapping and diet. Mamm Biol 79:123-131. https://doi.org/ 10.1016/j.mambio.2013.11.004

Basille M, Fortin D, Dussault C, Ouellet JP, Courtois R (2013) Ecologically based definition of seasons clarifies predator-prey interactions. Ecography 36:220-229. https://doi.org/10.1111/j.16000587.2011.07367.x

Bassi E, Donaggio E, Marcon A, Scandura M, Apollonio M (2012) Trophic niche overlap and wild ungulate consumption by red fox and wolf in a mountain area in Italy. Mamm Biol 77:369-376. https://doi.org/10.1016/j.mambio.2011.12.002

Boitani L, Mattei L, Nonis D, Corsi F (1994) Spatial and activity patterns of wild boars in Tuscany, Italy. J Mammal 75:600-612. https://doi. org/10.2307/1382507

Bonnot N, Morellet N, Verheyden H, Cargnelutti B, Lourtet B, Klein F, Hewison AM (2013) Habitat use under predation risk: hunting, roads and human dwellings influence the spatial behaviour of roe deer. Eur J Wildlife Res 59:185-193. https://doi.org/10.1007/ s10344-012-0665-8

Bu H, Wang F, McShea WJ, Lu Z, Wang D, Li S (2016) Spatial cooccurrence and activity patterns of mesocarnivores in the temperate forests of Southwest China. PLoS One 11:e0164271. https://doi.org/ 10.1371/journal.pone.0164271

Cagnacci F, Lovari S, Meriggi A (2003) Carrion dependence and food habits of the red fox in an Alpine area. Ital J Zool 70:31-38. https:// doi.org/10.1080/11250000309356493

Campbell TA, Long DB (2010) Activity patterns of wild boars (Sus scrofa) in Southern Texas. Southwest Nat 55:564-567. https://doi. org/10.1894/TAL-15.1

Caniglia R, Fabbri E, Greco C, Galaverni M, Manghi L, Boitani L, Sforzi A, Randi E (2013) Black coats in an admixed wolf $\times$ dog pack is melanism an indicator of hybridization in wolves? Eur J Wildlife Res 59:543-555. https://doi.org/10.1007/s10344-013-0703-1

Cavallini P, Lovari S (1991) Environmental factors influencing the use of habitat in the red fox, Vulpes vulpes. J Zool 223:323-339

Cavallini P, Lovari S (1994) Home range, habitat selection and activity of the red fox in a Mediterranean coastal ecotone. Acta Theriol 39:279 287. https://doi.org/10.4098/AT.arch.94-31

Chapron G, Kaczensky P, Linnell JDC, von Arx M, Huber D, Andrén H, López-Bao JV, Adamec M, Álvares F, Anders O, Balčiauskas L, Balys V, Bedő P, Bego F, Blanco JC, Breitenmoser U, Brøseth H, Bufka L, Bunikyte R, Ciucci P, Dutsov A, Engleder T, Fuxjäger C, Groff C, Holmala K, Hoxha B, Iliopoulos Y, Ionescu O, Jeremić J, Jerina K, Kluth G, Knauer F, Kojola I, Kos I, Krofel M, Kubala J, Kunovac S, Kusak J, Kutal M, Liberg O, Majić A, Männil P, Manz R, Marboutin E, Marucco F, Melovski D, Mersini K, Mertzanis Y, Mysłajek RW, Nowak S, Odden J, Ozolins J, Palomero G, Paunović M, Persson J, Potočnik H, Quenette PY, Rauer G, Reinhardt I, Rigg R, Ryser A, Salvatori V, Skrbinšek T, Stojanov A, Swenson JE, Szemethy L, Trajçe A, Tsingarska-Sedefcheva E, Váňa M, Veeroja R, Wabakken P, Wölfl M, Wölfl S, Zimmermann F, Zlatanova D, Boitani L (2014) Recovery of large carnivores in 
Europe's modern human-dominated landscapes. Science 346:15171519. https://doi.org/10.1126/science. 1257553

Ciampalini B, Lovari S (1985) Food habits and trophic niche overlap of the badger and the red fox in a Mediterranean coastal area. Z Saugetierkd 45:226-234

Ciucci P, Mancinelli S, Boitani L, Gallo O, Grottoli L (2020) Anthropogenic food subsidies hinder the ecological role of wolves: insights for conservation of apex predators in human-modified landscapes. Glob Ecol Conserv 21:e00841. https://doi.org/10.1016/j. gecco.2019.e00841

Corsini MT, Lovari S, Sonnino S (1995) Temporal activity patterns of crested porcupines Hystrix cristata. J Zool 236:43-54

Courbin N, Fortin D, Dussault C, Fargeot V, Courtois R (2013) Multitrophic resource selection function enlightens the behavioural game between wolves and their prey. J Anim Ecol 82:1062-1071. https:// doi.org/10.1111/1365-2656.12093

Creel S, Winnie JA (2005) Responses of elk herd size to fine-scale spatial and temporal variation in the risk of predation by wolves. Anim Behav 69:1181-1189. https://doi.org/10.1016/j.anbehav.2004.07. 022

Crooks KR, Soulé ME (1999) Mesopredator release and avifaunal extinctions in a fragmented system. Nature 400:563-566

de Satgé J, Teichman K, Cristescu B (2017) Competition and coexistence in a small carnivore guild. Oecologia 184:873-884. https://doi.org/ 10.1007/s00442-017-3916-2

Donadio E, Buskirk SW (2006) Diet, morphology, and interspecific killing in carnivora. Am Nat 167:524-536. https://doi.org/10.1086/ 501033

Dröge E, Creel S, Becker MS, M'soka J (2017) Risky times and risky places interact to affect prey behaviour. Nat Ecol Evol 1:1123-1128. https://doi.org/10.1038/s41559-017-0220-9

Estes JA, Palmisano JF (1974) Sea otters: their role in structuring nearshore communities. Science 185:1058-1060

Estes JA, Terborgh J, Brashares JS et al (2011) Trophic downgrading of planet earth. Science 333:301-306. https://doi.org/10.1126/science. 1205106

Ferretti F, Fattorini N (2020) Competitor densities, habitat and weather: effects on interspecific interactions between wild deer species. Integr Zool (published online). https://doi.org/10.1111/1749-4877.12470

Ferretti F, Lovari S, Mancino V, Burrini L, Rossa M (2019) Food habits of wolves and selection of wild ungulates in a prey-rich Mediterranean coastal area. Mamm Biol 99:119-127. https://doi. org/10.1016/j.mambio.2019.10.008

Ferretti F, Sforzi A, Lovari S (2011) Behavioural interference between ungulate species: roe are not on velvet with fallow deer. Behav Ecol Sociobiol 65:875-887. https://doi.org/10.1007/s00265-010-1088-8

Ferretti F, Pacini G, Belardi I, ten Cate B, Sensi M, Oliveira R, Rossa M, Burrini L, Lovari S (2021) Recolonizing wolves and opportunistic foxes: interference or facilitation? Biol J Linn Soc 132:196-210

Fischhoff IR, Sundaresan SR, Cordingley J, Rubenstein D (2007) Habitat use and movements of plains zebra (Equus burchelli) in response to predation danger from lions. Behav Ecol 18:725-729. https://doi. org/10.1093/beheco/arm036

Flagel DG, Belovsky GE, Beyer DE (2016) Natural and experimental tests of trophic cascades: gray wolves and white-tailed deer in a Great Lakes forest. Oecologia 180:1183-1194. https://doi.org/10. 1007/s00442-015-3515-Z

Ford AT, Goheen JR, Otieno TO, Bidner L, Isbell LA, Palmer TM, Ward D, Woodroffe R, Pringle RM (2014) Large carnivores make savanna tree communities less thorny. Science 346:346-349. https://doi. org/10.1126/science. 1252753

Fortin D, Beyer HL, Boyce MS, Smith DW, Duchesne T, Mao JS (2005) Wolves influence elk movements: behavior shapes a trophic cascade in Yellowstone National Park. Ecology 86:1320-1330. https://doi. org/10.1890/04-0953
Foster VC, Sarmento P, Sollmann R, Tôrres N, Jácomo AT, Negrões N, Fonseca C, Silveira L (2013) Jaguar and puma activity patterns and predator-prey interactions in four Brazilian biomes. Biotropica 45: 373-379. https://doi.org/10.1111/btp.12021

Gandolfi M (2004) Food habits of the badger Meles meles (L., 1758) in a Mediterranean area: a new evaluation [in Italian]. BSc thesis, University of Siena, Siena, Italy

Haswell PM, Jones KA, Kusak J, Hayward MW (2018) Fear, foraging and olfaction: how mesopredators avoid costly interactions with apex predators. Oecologia 187:573-583. https://doi.org/10.1007/ s00442-018-4133-3

Haswell PM, Kusak J, Jones KA, Hayward MW (2020) Fear of the dark? A mesopredator mitigates large carnivore risk through nocturnality, but humans moderate the interaction. Behav Ecol Sociobiol 74:62. https://doi.org/10.1007/s00265-020-02831-2

Hebblewhite M, White CA, Nietvelt CG, McKenzie JA, Hurd TE, Fryxell JM, Bayley SE, Paquet P (2005) Human activity mediates a trophic cascade caused by wolves. Ecology 86:2135-2144

Ivlev VS (1961) Experimental ecology of the feeding of fishes. Yale University Press, New Haven

Jarnemo A, Liberg O, Lockowandt S, Olsson A, Wahlstrom K (2004) Predation by red fox on European roe deer fawns in relation to age, sex and birth date. Can J Zool 82:416-422

Kronfeld-Schor N, Dayan T (2003) Partitioning of time as an ecological resource. Annu Rev Ecol Evol S 34:153-181. https://doi.org/10. 1146/annurev.ecolsys.34.011802.132435

Kuijper DPJ, de Kleine C, Churski MV, van Hooft P, Bubnicki J, Jędrzejewska B (2013) Landscape of fear in Europe: wolves affect spatial patterns of ungulate browsing in Białowieża Primeval Forest, Poland. Ecography 36:1263-1275

Kuijper DPJ, Bubnicki JW, Churski M, Mols B, Van Hooft P (2015) Context dependence of risk effects: wolves and tree logs create patches of fear in an old-growth forest. Behav Ecol 26:1558-1568. https://doi.org/10.1093/beheco/arv107

Kuijper DPJ, Sahlén E, Elmhagen B, Chamaillé-Jammes S, Sand H, Lone K, Cromsigt JPGM (2016) Paws without claws? Ecological effects of large carnivores in anthropogenic landscapes. Proc R Soc B 283: 20161625. https://doi.org/10.1098/rspb.2016.1625

Li S, Mcshea WJ, Wang D, Shao L, Shi X (2010) The use of infraredtriggered cameras for surveying phasianids in Sichuan Province, China. Ibis 152:299-309. https://doi.org/10.1111/j.1474-919X. 2009.00989.x

Li S, McShea WJ, Wang D, Lu Z, Gu X (2012) Gauging the impact of management expertise on the distribution of large mammals across protected areas. Divers Distrib 18:1166-1176. https://doi.org/10. 1111/j.1472-4642.2012.00907.x

Liley S, Creel S (2008) What best explains vigilance in elk: characteristics of prey, predators, or the environment? Behav Ecol 19:245-254. https://doi.org/10.1093/beheco/arm116

Lima SL (2002) Putting predators back into behavioral predator-prey interactions. Trends Ecol Evol 17:70-75. https://doi.org/10.1016/ S0169-5347(01)02393-X

Linkie M, Ridout MS (2011) Assessing tiger-prey interactions in Sumatran rainforests. J Zool 284:224-229. https://doi.org/10.1111/ j.1469-7998.2011.00801.x

Lone K, Loe LE, Gobakken T, Linnell JD, Odden J, Remmen J, Mysterud A (2014) Living and dying in a multi-predator landscape of fear: roe deer are squeezed by contrasting pattern of predation risk imposed by lynx and humans. Oikos 123:641-651. https://doi.org/ 10.1111/j.1600-0706.2013.00938.x

Lovari S, Corsini MT, Guazzini B, Romeo G, Mori E (2017) Suburban ecology of the crested porcupine in a heavily poached area: a global approach. Eur J Wildlife Res 63:10. https://doi.org/10.1007/s10344016-1075-0

Lucherini M, Reppucci JI, Walker RS, Villalba ML, Wurstten A, Gallardo G, Iriarte A, Villalobos R, Perovic P (2009) Activity 
pattern segregation of carnivores in the High Andes. J Mammal 90: 1404-1409

Lund U, Agostinelli C, Arai H, Gagliardi A, Portugues EG, Giunchi D, Irisson JO, Pocernich M, Rotolo F (2017) Circular Statistics, https:// cran.r-project.org/web/packages/circular/circular.pdf

Martin J, Chamaillé-Jammes S, Waller DM (2020) Deer, wolves, and people: costs, benefits and challenges of living together. Biol Rev 95:782-801. https://doi.org/10.1111/brv.12587

Mastroianni O (2004) Food habits of the badger: evaluation of two methods [in Italian]. BSc thesis, University of Siena, Siena, Italy

Mech LD (2012) Is science in danger of sanctifying the wolf? Biol Conserv 150:143-149. https://doi.org/10.1016/j.biocon.2012.03.003

Melini D, Agrillo E, Ferretti F, Tonelli L (2019) Piano di Gestione della ZSC/ZPS IT51A0016 Monti dell'Uccellina. Ente Parco Regionale della Maremma, Alberese

Meredith M, Ridout M (2017) Overlap: estimates of coefficient of overlapping for animal activity patterns, https://cran.r-project.org/web/ packages/overlap/overlap.pdf

Monterroso P, Alves PC, Ferreras P (2013) Catch me if you can: diel activity patterns of mammalian prey and predators. Ethology 119 : 1044-1056. https://doi.org/10.1111/eth.12156

Monterroso P, Alves PC, Ferreras P (2014) Plasticity in circadian activity patterns of mesocarnivores in Southwestern Europe: implications for species coexistence. Behav Ecol Sociobiol 68:1403-1417. https://doi.org/10.1007/s00265-014-1748-1

Mori E, Bagnato S, Serroni P, Sangiuliano A, Rotondaro F, Marchianò V, Cascini V, Poerio L, Ferretti F (2020) Spatiotemporal mechanisms of coexistence in an European mammal community in a protected area of southern Italy. J Zool 310:232-245. https://doi.org/10.1111/ jzo. 12743

Mori E, Benatti L, Lovari S, Ferretti F (2016) What does the wild boar mean to the wolf? Eur J Wildlife Res 63:9. https://doi.org/10.1007/ s10344-016-1060-7

Mori E, Maggini I, Menchetti M (2013) When quills kill: the defense strategy of the crested porcupine Hystrix cristata L., 1758. Mammalia 78:229 234. https://doi.org/10.1515/mammalia-2013-0126

Mori E, Nourisson DH, Lovari S, Romeo G, Sforzi A (2014) Self-defence may not be enough: moonlight avoidance in a large, spiny rodent. $\mathrm{J}$ Zool 294:31-40. https://doi.org/10.1111/jzo.12145

Niglio M (1995) Home range, ritmi di attivita' e scelta dell'habitat di femmine di daino nel Parco Regionale della Maremma. MSc thesis, Università degli Studi di Bologna

Oberosler V, Groff C, Iemma A, Pedrini P, Rovero F (2017) The influence of human disturbance on occupancy and activity patterns of mammals in the Italian Alps from systematic camera trapping. Mamm Biol 87:50 61. https://doi.org/10.1016/j.mambio.2017.05.005

Palomares F, Caro TM (1999) Interspecific killing among mammalian carnivores. Am Nat 153:492-508. https://doi.org/10.1086/303189

Palomares F, Ferreras P, Fedriani JM, Delibes M (1996) Spatial relationships between Iberian lynx and other carnivores in an area of southwestern Spain. J Appl Ecol 33:5-13

Pasanen-Mortensen M, Pyykönen M, Elmhagen B (2013) Where lynx prevail, foxes will fail - limitation of a mesopredator in Eurasia. Glob Ecol Biogeogr 22:868-877. https://doi.org/10.1111/geb. 12051

Périquet S, Valeix M, Loveridge AJ, Madzikanda H, Macdonald DW, Fritz H (2010) Individual vigilance of African herbivores while drinking: the role of immediate predation risk and context. Anim Behav 79:665-671. https://doi.org/10.1016/j.anbehav.2009.12.016

Pratas-Santiago LP, Gonçalves ALS, da Maia Soares AMV, Spironello WR (2016) The moon cycle effect on the activity patterns of ocelots and their prey. J Zool 299:275-283. https://doi.org/10.1111/jzo. 12359

Prugh LR, Sivy KJ (2020) Enemies with benefits: integrating positive and negative interactions among terrestrial carnivores. Ecol Lett 23:902 918. https://doi.org/10.1111/ele.13489
Core Team R (2020) R: a language and environment for statistical computing. R Foundation for Statistical Computing, Vienna https:// www.R-project.org/

RDM (2002) Piano di gestione forestale. Ente Parco Regionale della Maremma. Alberese, Italy

Ridout MS, Linkie M (2009) Estimating overlap of daily activity patterns from camera trap data. J Agric Biol Environ Stat 14:322-337. https://doi.org/10.1198/jabes.2009.08038

Ripple WJ, Beschta RL, Fortin JK, Robbins CT (2014) Trophic cascades from wolves to grizzly bears in Yellowstone. J Anim Ecol 83:223233. https://doi.org/10.1111/1365-2656.12123

Ritchie EG, Johnson CN (2009) Predator interactions, mesopredator release and biodiversity conservation. Ecol Lett 12:982-998. https:// doi.org/10.1111/j.1461-0248.2009.01347.x

Rosalino LM, Macdonald DW, Santos-Reis M (2005) Activity rhythms, movements and patterns of sett use by badgers, Meles meles, in a Mediterranean woodland. Mammalia 69:395-408

Ross J, Hearn AJ, Johnson PJ, Macdonald DW (2013) Activity patterns and temporal avoidance by prey in response to Sunda clouded leopard predation risk. J Zool 290:96-106. https://doi.org/10.1111/jzo. 12018

Rowcliffe JM, Field J, Turvey ST, Carbone C (2008) Estimating animal density using camera traps without the need for individual recognition. J Appl Ecol 45:1228-1236. https://doi.org/10.1111/j.13652664.2008.01473.x

Schmitz OJ, Hambäck PA, Beckerman AP (2000) Trophic cascades in terrestrial systems: a review of the effects of carnivore removals on plants. Am Nat 155:141-153. https://doi.org/10.1086/303311

Schoener TW (1974) Resource partitioning in ecological communities. Science 185:27-39. https://doi.org/10.1126/science.185.4145.27

Selva N, Fortuna MA (2007) The nested structure of a scavenger community. Proc R Soc Lond B 274:1101-1108. https://doi.org/10. 1098/rspb.2006.0232

Selva N, Jędrzejewska B, Jędrzejewski W, Wajrak A (2005) Factors affecting carcass use by a guild of scavengers in European temperate woodland. Can J Zool 83:1590-1601. https://doi.org/10.1139/z05158

Sforzi A, Tonelli L, Selva FC, Mastacchi R, Lanzi L, Anselmi G, Martini G, Naviglio L (2012) Piano di Gestione dei SIC/SIR - IT51A0039 [SIE 113 e A113(ZPS)] Palude della Trappola e Bocca d'Ombrone, IT51A0014 [SIR 114] Pineta Granducale dell'Uccellina e IT51A0015 [SIR 115] Dune costiere del Parco dell'Uccellina. Ente Parco Regionale della Maremma, Alberese

Sinclair ARE, Mduma S, Brashares JS (2003) Patterns of predation in a diverse predator-prey system. Nature 425:288-290. https://doi.org/ 10.1038/nature01934

Sivy KJ, Pozzanghera CB, Colson KE, Mumma MA, Prugh LR (2018) Apex predators and the facilitation of resource partitioning among mesopredators. Oikos 127:607-621. https://doi.org/10.1111/oik. 04647

Smith JA, Donadio E, Pauli JN, Sheriff MJ, Middleton AD (2019) Integrating temporal refugia into landscapes of fear: prey exploit predator downtimes to forage in risky places. Oecologia 189:883890. https://doi.org/10.1007/s00442-019-04381-5

Sönnichsen L, Bokje M, Marchal J, Hofer H, Jędrzejewska B, KramerSchadt S, Ortmann S (2013) Behavioural responses of European roe deer to temporal variation in predation risk. Ethology 119:233-243. https://doi.org/10.1111/eth.12057

Soulé ME, Bolger DT, Alberts AC, Wrights J, Sorice M, Hill S (1988) Reconstructed dynamics of rapid extinctions of chaparral-requiring birds in urban habitat islands. Conserv Biol 2:75-92

Tambling CJ, Minnie L, Meyer J, Freeman EW, Santymire RM, Adendorff J, Kerley GI (2015) Temporal shifts in activity of prey following large predator reintroductions. Behav Ecol Sociobiol 69: 1153-1161. https://doi.org/10.1007/s00265-015-1929-6 
Theuerkauf J (2009) What drives wolves: fear or hunger? Humans, diet, climate and wolf activity patterns. Ethology 115:649-657. https:// doi.org/10.1111/j.1439-0310.2009.01653.x

Theuerkauf J, Jędrzejewski W, Schmidt K, Okarma H, Ruczyński I, Śniezko S, Gula R (2003) Daily patterns and duration of wolf activity in the Białowieza Forest, Poland. J Mammal 84:243-253. https:// doi.org/10.1644/1545-1542(2003)084<0243:DPADOW>2.0.CO;2

Tobler MW, Carrillo-Percastegui SE, Leite Pitman R, Mares R, Powell G (2008) An evaluation of camera traps for inventorying large- and medium-sized terrestrial rainforest mammals. Anim Conserv 11: 169-178. https://doi.org/10.1111/j.1469-1795.2008.00169.x

Torretta E, Mosini A, Piana M, Tirozzi P, Serafini M, Puopolo F, Saino $\mathrm{N}$, Balestrieri A (2017) Time partitioning in mesocarnivore communities from different habitats of NW Italy: insights into martens' competitive abilities. Behaviour 154:241-266. https://doi.org/10. 1163/1568539X-00003420

Torretta E, Serafini M, Puopolo F, Schenone L (2016) Spatial and temporal adjustments allowing the coexistence among carnivores in Liguria (N-W Italy). Acta Ethol 19:123-132. https://doi.org/10. 1007/s10211-015-0231-y

Vanak AT, Thaker M, Gompper ME (2009) Experimental examination of behavioural interactions between free-ranging wild and domestic canids. Behav Ecol Sociobiol 64:279-287. https://doi.org/10.1007/ s00265-009-0845-z
Weckel M, Giuliano W, Silver S (2006) Jaguar (Panthera onca) feeding ecology: distribution of predator and prey through time and space. $\mathrm{J}$ Zool 270:25-30. https://doi.org/10.1111/j.1469-7998.2006.00106.x

Weitzman MS (1970) Measure of overlap of income distributions of white and negro families in the United States. US Government Printing Office, Washington

Wikenros C, Aronsson M, Liberg O, Jarnemo A, Hansson J, Wallgren M, Sand H, Bergström R (2017) Fear or food - abundance of red fox in relation to occurrence of lynx and wolf. Sci Rep 7:9059. https://doi. org/10.1038/s41598-017-08927-6

Wikenros C, Sand H, Ahlqvist P, Liberg O (2013) Biomass flow and scavengers use of carcasses after re-colonization of an apex predator. PLoS One 8:e77373. https://doi.org/10.1371/journal.pone.0077373

Wirsing AJ, Cameron KE, Heithaus MR (2010) Spatial responses to predators vary with prey escape mode. Anim Behav 79:531-537. https://doi.org/10.1016/j.anbehav.2009.12.014

Yang H, Zhao X, Han B, Wang T, Mou P, Ge J, Feng L (2018) Spatiotemporal patterns of Amur leopards in northeast China: influence of tigers, prey, and humans. Mamm Biol 92:120-128. https:// doi.org/10.1016/j.mambio.2018.03.009

Publisher's note Springer Nature remains neutral with regard to jurisdictional claims in published maps and institutional affiliations. 